\title{
PUNAN LONGSEP: WACANA YANG BETERBANGAN PADA ORANG PUNAN DI TENGAH AREAL HAK GUNA USAHA DI KALIMANTAN TIMUR
}

\section{Damasus Ferix Loys Hermawan}

Program Pascasarjana Ilmu Religi Budaya, Universitas Sanata Dharma Yogyakarta, Indonesia Email:damzfx@gmail.com

\begin{abstract}
Punan Longsep is one of other original inhabitant of the forests on Borneo who depend their live of forest commodity. Their transition activities managing and obtaining forest product are disturbed by the transition of forest function. In Longsep (which is included in the transition areal of forest functions) there has been an interaction between Punan and HGU license holders or other groups. Interaction and communication thats led into various discourses to a variety of floating discourses. Furthermore, these discourses are negotiated to be part of the fulfillment of life needs. Many discourses have obtained by conducting live. Experience shows that there is a dominant discourse. Among discourses, there is a discourse that become a main role for Punan's life. This discourse reinforces the hypothesa that there is a dominantion for Punan. The domination seems in the changing of Punan's people. The main discourse domination that is appeared in their live is about "company discourse". This discourse builds and shapes their life of Punans, that probably changes their orientation and perspective on companies in Longsep, that makes Punan only depend on the companies and can not do anything without the company. The dominance discourse seems to be the basic transformation of life practice for Punan.
\end{abstract}

Keyword; Transition of forest function; Puna; Negotiation; Discourse; Domination

\section{Pendahuluan}

Salah satu penghuni asli pulau Kalimantan adalah Punan. Sebagai kelompok yang hidup di hutan, mereka banyak didefinisikan sebagai kelompok yang nomaden. Dalam kehidupannya, mereka mengandalkan hasil hutan secara subsisten maupun sebagai sumber pendapatan tunai. (Sidorus. dkk, 2004 : iv) ${ }^{1}$. Dalam esainya, Hoffman (1988:90) menulis tentang perjalanan Carl Bock yang seorang petualang dan naturalis pada tahun 1870 masuk ke dalam hutan yang kini dikenal dengan distrik Muara Wahau untuk memperoleh keterangan tentang keberadaan Punan sebagai orang asli yang hidup liar dan tinggal didalam hutan Borneo jauh dari komunikasi luar. ${ }^{2}$ Definisi Carl Bock sedikit berbeda dengan yang diungkapkan oleh Nicholas Cesard (2007 : 455), ${ }^{3}$ menyatakan bahwa Punan merupakan kelompok kecil yang berburu dan mengumpulkan hasil hutan mereka biasa tinggal di hulu kampung dayak. Menurutnya, Punan dan Dayak merupakan sebutan untuk mengklasifikasi 
kelompok pertanian yang nonstratified dan stratified.

Berbagai definisi terhadap Punan telah diperoleh dari penelitian-penelitian terdahulu. Artikel ini mencoba untuk menawarkan pandangan berbeda dalam mendefinisikan dan menggambarkan Punan. Punan yang hendak didefinisikan kembali adalah kelompok Punan Longsep yang tinggal ditengah areal Hak Guna Usaha perusahaan kelapa sawit di kalimantan Timur. Perubahan pada kelompok ini merupakan pangkal atas perbedaan definisi yang ditawarkan.

Di daerah Sungai Wahau telah ada Dayak Wehea dan Dayak Kayan (pindahan dari Sungai Apokayan pada tahun 1971), sebelum kedatangan Orang Punan Longsep di daerah Sungai Wahau pada tahun 1979. Sebelumnya mereka adalah bagian dari Punan yang ada di Sungai Ului Kelay Berau. Beberapa dari mereka yang terikat hutang dengan bos (sebutan untuk tengkulak/pedagang yang menjual hasil hutan yang mereka kumpulkan di hutan) dibawa ke daerah Sungai Seleq dan Sungai Wahau untuk bekerja mencari rotan dan kayu Gaharu sebagai ganti membayar hutang. ${ }^{4}$ Harga kayu Gaharu saat ini sekitar Rp.150.000/kg (potensi-indonesia.com) ${ }^{5}$ dan dahulu harga Kayu Gaharu antara Rp. 25.000 - Rp. 50.000/kg. ${ }^{6}$ Hasil yang mereka dapatkan dari bekerja dengan bos tidak mencukupi untuk melunasi hutang, kemudian menetap di daerah Longsep membuat mereka mulai meninggalkan aktivitas berburu serta mengumpulkan hasil hutan terlebih saat kehadiran perusahaan mengelola hutan.

Sebelum kedatangan Punan, di daerah dekat Longsep telah beroperasi perusahaan loging (kayu) seperti PT Gunung Gajah Abadi tahun 1973, PT Narkata Rimba tahun 1989 dan lainnya (belum dapat diinventaris). Dan saat ini setidaknya pada tahun 2017 Orang Punan di Longsep telah dikelilingi tanaman Kelapa Sawit setidaknya empat perusahaan perkebunan Kelapa Sawit. Lokasi tepat Longsep berada di tengah areal HGU (Hak Guna Usaha) perusahaan Kelapa Sawit. Orang Longsep kini jarang melakukan aktifitas pergi ke hutan. Selain karena mereka telah bekerja di perkebunan kelapa sawit, hutan telah mulai berkurang karena ekpoitasi kayu dan lahan untuk perkebunan. Menetapnya Orang Punan di Longsep bukan hanya karena alasan hal hutang saja, namun karena hampir semua "fasilitas hidup sebagai orang modern" telah diberi perusahaan. Lambat laun mulai berdatangan orang dari luar dan tinggal di Longsep.

Status Longsep yang berada tengah areal HGU memungkinkan terjadi negosiasi dan 
praktik dominasi wacana perusahaan dalam kehidupan Orang Punan di Longsep. Selain itu negosiasi Orang Punan terjadi pula dengan kelompok suku (Dayak Wehea dan Dayak Kayan) yang lebih dulu tiba di Sungai Wahau yang hasilnya menetapkan Longsep sebagai daerah kampungnya. ${ }^{7}$ Negosiasi juga dialami pada berbagai hal baru yang mereka dapatkan dengan kehadiran perusahaan. Mereka mengalami negosiasi terhadap kebutuhan elektronik (lampu, TV, sound system, VCD player), kebutuhan rohani, kebutuhan makanan (dimana mereka tidak lagi harus bercocok tanam atau berburu tetapi mereka harus membeli) dan kebutuhan pekerjaan (guna mendapatkan uang). Negosiasi-negosiasi inilah yang mencerminkan berbagai wacana, terutama wacana dominan yang membatasi pergerakan hidup Orang Punan di Longsep.

Peralihan fungsi hutan menjadi lahan industri merupakan titik awal keberangkatan kita untuk memahami fenomena ini. HGU adalah hak khusus untuk mengusahakan tanah yang bukan miliknya sendiri atas tanah yang dikuasai langsung oleh negara untuk perusahaan pertanian atau peternakan hal ini menurut Pasal 28 Undang-undang Nomor 5 Tahun 1960 Tentang Pokok-pokok Agraria (UUPA). ${ }^{8}$ Kini pengelolaan atau penerbitan izin Hak Pakai, Hak Guna Bangunan, Hak Guna Usaha adalah kewenangan dari pemerintah lokal yaitu Kepala Kantor Wilayah Pertanahan. Hal ini sesuai dengan Peraturan Kepala Badan Pertanahan Nasional Republik Indonesia Nomor 2 tahun 2013. Kebijakan ini sesuai dalam Peraturan Menteri Agraria dan Tata Ruang/ Kepala Bidang Badan Pertanahan Nasional Nomor 7 Tahun 2017. Jangka waktu izin HGU adalah 25 tahun, sedangkan umur produktif Kelapa Sawit 25 tahun oleh karena itu perusahaan perkebunan Kelapa Sawit dapat mengajukan perpanjangan jangka waktu. Luasan dalam suatu izin HGU yang telah terbit tentu akan dimaksimalkan pengelolaannya oleh pihak yang mendapatkan izin.

Tanaman kelapa sawit telah menjadi komoditas 'penting' karena dianggap terbukti menghasilkan banyak untung bagi orang yang bergelut dengan bidang ini. Kemudian tidak mengherankan bila banyak ditemukan Kelapa Sawit di Kalimantan Timur, bahkan sepanjang perjalanan dari Ibu Kota Kabupaten Kutai Timur sampai di kecamatan Muara Wahau pandangan mata 'dibiasakan' melihat pohon kelapa sawit, ini menunjukkan bahwa sawit merupakan komoditi 'primadona'.

Sebagai komoditi yang dianggap telah memberikan bukti keuntungan nyata, Sawit 
menjadi primadona. Sedangkan Longsep (kampung Punan) yang merupakan daerah hasil enclave perusahaan sawit juga merasakan efek nyata atas kehadiran komoditi unggulan ini. Hal ini terlihat dari berbagai perubahan pola hidup yang dialami Orang Punan Longsep. Perubahan tersebut merupakan bagian dari hasil negosiasi Orang Punan di Longsep terhadap wacana yang ada.

Berpegang pada hal tersebut, maka dirumuskan pertanyaan penelitian mengenai "Bagaimana negosiasi yang dialami Orang Punan Longsep atas keberadaannya di tengah HGU?" pertanyaan ini sebagai pedoman mengidentifikasi wacana yang ada.

\section{Metode penelitian}

Penelitian diawali dengan observasi yang telah dilakukan pada 26 - 30 November 2017. Pengumpulkan data dilakukan dengan studi live experience etnografi, dengan menjalin kedekatan serta mengamati aktivitas kehidupan dengan dokumentasi fotografi dan interview beberapa tokoh Orang Punan Longsep dan juga pada pihak perusahaan terlebih CSR (Corporate Social Resposibility) sebagai departemen yang membidangi perihal Longsep. Penelitian lebih mendalam akan dilakukan kemudian.

\section{Hasil dan Pembahasan}

\subsection{Gambaran Umum Longsep}

Stereotipe Orang Punan yang 'di/terkenal' dengan liar, tak beradab, terbelakang nampak berbeda dengan yang dijalani Orang Punan di Longsep yang keberadaanya di dalam areal HGU perusahaan. Mereka dituntut untuk mampu beradaptasi dengan keberadaan perusahaan Kelapa Sawit. Adaptasi ini membuat mereka bernegosiasi dan harus mengalami perubahan dalam kehidupan. Berbagai perubahan telah dialami. Kedekatan dan seringnya interaksi mereka dengan karyawan atau pihak perusahaan adalah hal yang memicu terjadinya negosiasi. Hasil kedekatan' itu terlihat pada pembangunan berjangka rumah semi permanen (layak huni), pembangunan areal kebun buah, pembangunan kebun kemitraan, pembangunan sanitasi/ jamban, akses jalan dan lainnya. Hampir semua fasilitas hidup Orang Punan di Longsep diberikan oleh perusahaan yang secara tidak langsung membuat mereka berada dalam dominasi peraturan perusahaan.

Secara umum Punan disebut sebagai kelompok penghuni asli hutan Borneo yang asing, tertutup dan terbelakang mengandalkan hutan serta aktivitas tukar menukar sebagai aktivitas hidupnya. Definisi tersebut perlu dipahami kembali dengan melihat Orang Punan Longsep. 
Longsep merupakan suatu sebutan untuk areal sekitar sungai Wahau yang termasuk dalam areal Hak Guna Usaha (HGU) sebuah perusahaan kelapa sawit di Kalimantan Timur. Secara adminstrasi negara Longsep berada dalam wilayah administrasi Desa Muara Wahau, Kecamatan Muara Wahau, Kabupaten Kutai Timur, Kalimantan Timur. ${ }^{9}$ Perjalanan pajang dilalui Orang Punan untuk sampai di Longsep. Sebelumnya mereka adalah bagian dari suku Punan yang ada di ujung sungai Ului Kelay, Berau. Perjalanan darat dari Kecamatan Muara Wahau ke Kecamatan Kelay sekitar $200 \mathrm{~km}$, belum dengan jarak masuk menuju lokasi Longsep dan sungai Ului. Sebelum menempati Longsep, bos dan beberapa orang yang bersamanya mendirikan sebuah pondok singgah dan bersama orang Dayak Kayan membangun rumah panjang di hulu Desa Miau Baru. Singkatnya hasil negosiasi dengan orang Miau Baru (Dayak Kayan) dan orang Nehas Liah Bing (Dayak Wehea) mereka membuka ladang dan menempati sebuah areal yang disepakati yaitu Longsep. Keberadaan Orang Punan di Longsep jauh sebelum kehadiran perusahaan kelapa sawit yang masuk pada tahun 2008 (dan tanam perdana di kebun inti mulai sekitar tahun 2009/2010) ${ }^{10}$ sedangkan perusahaan kayu telah ada sejak tahun 1974.
Gambar 1. Foto Data Jemaat GKII Longsep 2017

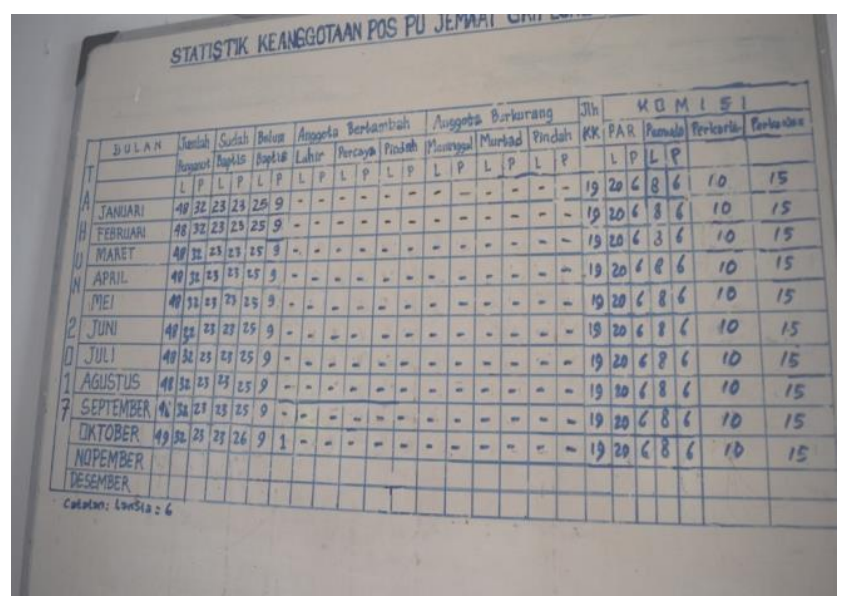

Sumber: Dokumentasi pribadi

Gambar 1 menunjukkan bahwa warga Longsep adalah penganut Kristen. Catatan dari bulan Januari-Oktober 2017 pengikut gereja terdiri dari 19 KK (Kepala Keluarga), dengan jumlah total pengikut 49 laki-laki dan 25 perempuan. Telah berdiri satu bangunan gereja di Longsep bahkan terlihat terakhir kali ada kerangka bangunan gereja baru yang akan di bangun. (Pembangunan gereja ini atas inisiatif dari gereja pusat di Desa Miau Baru) ${ }^{11}$ Ini menandakan bahwa wacana religius tentang konsep Tuhan telah mereka kenal dan dapatkan. Pada gambar.1 terlihat bahwa penduduk Longsep adalah penganut Kristen. Dalam tabel tersebut dipahami bahwa wacana religius telah masuk dalam pola kehidupan Orang Punan di Longsep. Bahkan berdasarkan wawancara yang dilakukan dengan Awun salah satu tokoh Orang Punan, mengaku bahwa dia telah mengenal agama Kristen sejak berada di Kelay Berau. Pernyataan itu memberikan 
informasi bahwa sebagian dari Orang Punan di Kelay juga telah kenal agama.

Keberadaan Orang Punan di Longsep bukan merupakan bagian dari program pemerintah yang pada masa Orde Baru gencar dengan istilah Respen (Restlement Penduduk). Meraka telah melakukan perjalanan dari Sungai Ului Kelay Berau ke daerah Muara Wahau dengan niat pemenuhan kebutuhan hidup. Orang Punan menetap di Longsep telah cukup lama bahkan telah beranak dan ada yang telah bercucu. Jadi menarik bahwa Orang Punan yang didefinisikan banyak ilmuwan sebagai kelompok yang liar, menolak untuk beradaptasi dan berkomunikasi dengan orang lain berbeda dengan mereka di Longsep yang telah mengenal agama dan berbagai interaksi dengan pihak luar kelompoknya.

\subsection{Lokasi keberadaan Punan di Longsep}

Longsep yang merupakan areal HGU perusahaan telah di enclave atau dikeluarkan dari dalam wilayah izin HGU (seperti yang tercatat dalam Paragraf 4 Pasal 5 ayat 2 Peraturan Mentri Agraria dan Tata Ruang/ Kepala Badan Pertanahan Nasional No 7 Tahun 2017 sebelum terbitnya peraturan Mentri No 7 Tahun 2017 tentang Peraturan dan Tata Cara Penetapan Hak Guna Usaha). Ini merupakan alasan perusahaan mengeluarkan sebagian areal izin lokasinya untuk Orang Punan di Longsep.

Gambar 2. Persebaran Perusahaan di Kutai Timur

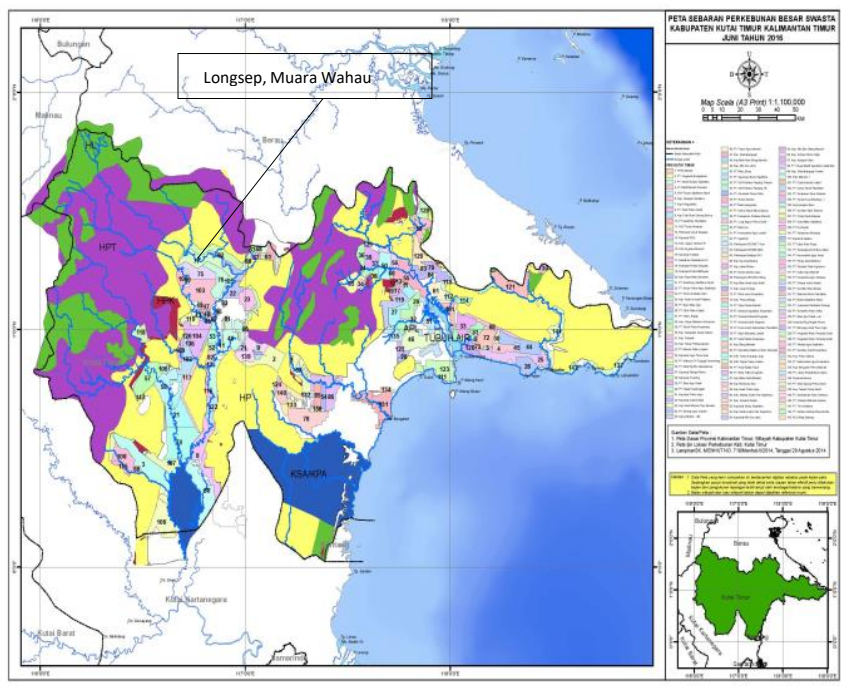

Sumber:disbun.kaltimprov.

Gambar 2 adalah lokasi tepat keberadaan Orang Punan di Longsep. Longsep berada dekat setidaknya empat perusahaan perkebunan Kelapa Sawit; PT Dewata Sawit Nusantara, PT Karya Agro Sejahtera, PT Nusantara Agro Sentosa dan Koperasi Seleq Sejahtera Bersama yang bermitra dengan PT Dewata Sawit Nusantara. Lokasi Longsep sebagian di jadikan kebun kemitraan tepatnya bermitra dengan PT Dewata Sawit Nusantara. Longsep berada dipinggir Sungai Wahau dan dikelilingi tanaman Kelapa Sawit. Akses warga Longsep terhadap fasilitas pemerintahan dan desa lain terhitung sekitar 1 jam lebih (sekitar 40 km) melewati empat areal izin HGU perusahaan dengan mengendarai kendaraan bermotor. 
3.3 Wacana-wacana yang berterbangan.

Setelah dipaparkan mengenai gambaran umum tentang Longsep, kemudian akan disajikan hasil identifikasi negosiasi terkait dengan wacana yang berkembang di Longsep.

Beberapa wacana tidak secara langsung dapat terekam/terlihat dari interaksi yang dilakukan pada saat observasi namun beberapa wacana berusaha di inventaris berdasarkan data yang diperoleh. Hal ini dengan tujuan untuk melihat seberapa banyak dan besar pengaruh wacana terhadap hidup Orang Punan di Longsep. Beberapa wacana yang dapat terinventarisir sebagai berikut:

\section{Wacana Religius}

Bangunan gereja telah ada di kampung pemukiman Longsep. Bangunan ini di Longsep merupakan simbol yang memperlihatkan adanya suatu korelasi antara bangunan tersebut dengan Orang Punan di Longsep. Keberadaan bangunan itu beserta peralatan ibadah dan pelayan agama akan memberikan penegasan terhadap tafsiran bahwa Orang Punan di Longsep telah mengenal Tuhan.
Gambar 3. Bangunan gereja dan aktivitas Anakanak Longsep bernyanyi didalam gereja

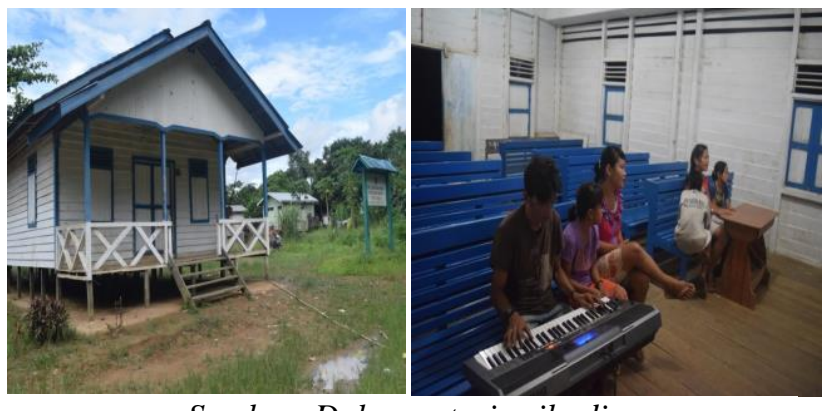

Sumber: Dokumentasi pribadi

Ketika dilakukan interaksi bersama anak-anak Longsep, mereka menyanyikan lagu-lagu rohani seperti judul "Kasihnya Seperti Sungai, "Kingkong Badannya Besar,"Yesus Kekasih Jiwaku" dan lain-lain. Ini merupakan artikulasi anak-anak terhadap wacana religius. Dalam hal ini wacana religius yang ada adalah konsep ajaran agama Kristen.

Agama sebagai cara pandang hidup terhadap fenomena sosial secara tidak langsung memberikan kontribusi pada Orang Punan untuk menyikapi keberadaannya di Longsep. Agama dianggap mampu memberikan jawaban untuk memaknai hidup mereka. Terselipnya istilah Tuhan dalam obrolan dan pemaknaan berbagai aktivitasnya kesehariannya sebagai campur tangan Tuhan adalah bukti wacana religius merasuk diri Orang Longsep. Seperti saat dilakukan wawancara dengan Awun, dia hampir selalu menyelipkan istilah"Tuhan dalam kesempatan obrolan. Dan ketika Awun menyatakan bahwa bantuan acara gereja 
selalu dari perusahaan ini menegaskan bagaimana peran perusahaan melalui campur tangannya pada gereja.. Hal ini tidak mengherankan karena Longsep berada ditengah areal HGU namun ketika dipahami lebih kritis bahwa kehadiran (usaha/peran) perusahaan merupakan strategi membentuk citranya melalui gereja.

Sebagai penganut ajaran Kristen Protestan Gereja Kemah Injili Indonesia (GKII) cabang dari Desa Miau Baru beberapa kali telah terselenggara kunjungan gereja lain ke Longsep. Interaksi dan komunikasi terjadi di Longsep atas peran agama. Gereja dalam hal ini agama Kristen yang pada praktiknya dekat dengan kehidupan turut memberikan kontribusi pada pemikiran orang Punan di Longsep. Agama mengajarkan tentang prinsip hidup, demikian juga tentang pemaknaan keberadaan mereka di Longsep. Dalam hal ini perusahaan memposisikan perannya dengan bantuan untuk berjalannya proses keagamaan. Seperti bantuan untuk pembangunan gereja, bantuan hari raya seperti Natal dan Paskah, atau kegiatan lainnya. Perusahaan turut membangun citranya dalam gereja melalui berbagai program bantuan tersebut.

2. Wacana Pendidikan

Wacana pendidikan di Longsep menggaung hampir pada semua kalangan. Sebagian anak
Longsep telah mengikuti studi belajar sekolah formal namun tidak dipungkiri bahwa ada beberapa anak tidak menyadari pentingnya pendidikan. Hampir semua anak Longsep mengikuti pendidikan sekolah dasar, hanya satu orang anak yang sudah lulus sekolah dasar namun tidak melajutkan sekolah menengah pertama karena permasalahan adminstrasi (tidak ada Akta Kelahiran).

\section{Gambar 4. Aktivitas anak Longsep berangkat} dan pulang sekolah
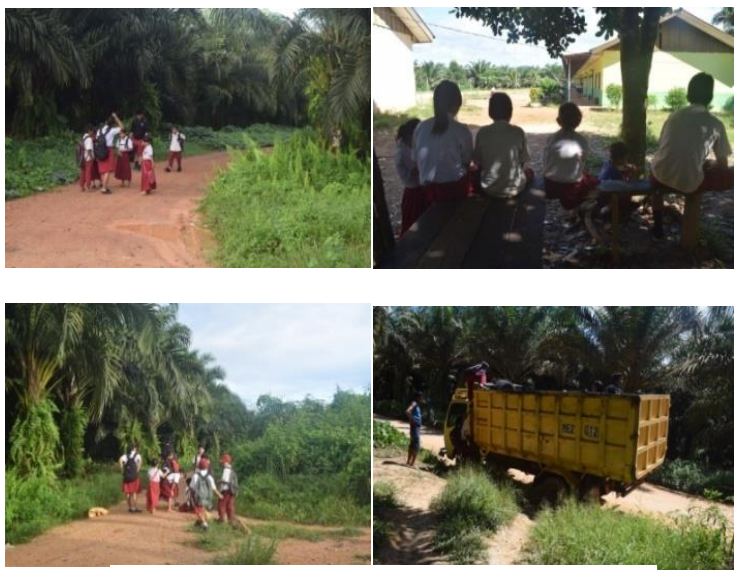

Sumber: Dokumentasi pribadi

Gambar 4 memperlihatkan bahwa anakanak Longsep memiliki rasa ingin untuk berpendidikan. Berdasarkan gambar tersebut ditafsirkan bahwa sesungguhnya mereka (anak-anak Longsep) antusias untuk mendapat pendidikan. Pada kesempatan ini tidak sempat diperoleh dokumentasi kegiatan dan suasana belajar dikarenakan beberapa guru merasa terganggu ketika pengambilan gambar dilakukan. Terlepas dari itu, tokohtokoh/orang tua Punan Longsep mendukung 
anaknya untuk mendapatkan pendidikan yang lebih baik. Hal ini terlihat pada pernyataan Awun pada saat wawancara dilakukan; “...selama ini anak-anak Longsep perlu dorongan, saya pun mendorong mereka agar mereka punya cita-cita, saya tidak ingin mereka seperti saya..., seperti apa yang saya rasakan......."12 Pernyataan Awun ini memberikan gambaran tentang kesadaran pendidikan pada sebagian Orang Punan di Longsep. Dan wacana pendidikan mulai di tempatkan sebagai bagian dari hidup mereka di Longsep. Wacana pendidikan terartikulasikan dalam pernyataan Awun dan antusiasme anak-anak Longsep untuk mengikuti kegiatan belajar.

Perusahaan berperan melalui dept CSR pada pendidikan formal dan informal disekitar areanya. Pada pendidikan formal perusahaan menyediakan fasilitas berupa transportasi serta bangunan sekolah, dan pada pendidikan informal dilakukan dengan program pendidikan dasar (baca, tulis, hitung) untuk anak-anak di semua desa sekitar perusahaan termasuk Longsep. Pada program infromal inilah interaksi anak-anak Longsep dengan karyawan perusahaan semakin dekat dalam kegiatan belajar. Secara tidak langsung/disadari komunikasi yang terjalin pada anak-anak Longsep dan karyawan CSR memungkinkan bagian dari strategi bahwa perusahaan adalah 'penolong' yang memberi pendidikan. Strategi ini dalam upaya untuk membentuk citra perusahaan dengan membangun cara pandang anak-anak dan warga Longsep bahwa keberadaan dan operasional perusahaan disekitarnya tidak berpengaruh buruk bagi hidup mereka.

3. Wacana Kelapa Sawit

Keberadaan Longsep di tengah areal HGU perusahaan perkebunan Kelapa Sawit menjadikan mereka akrab dengan tanaman sawit. Pohon sawit merupakan primadona yang dirasa telah memperlihatkan keuntungan bagi orang bergelut dibidang ini. Begitu juga Longsep, mereka pun menggantungkan hidup dari sawit. Tidak ada pilihan lain bagi mereka untuk menerima sawit, selain karena ada di sekeliling mereka terlebih karena hutan tempat mereka sandarkan hidup telah banyak yang 'hilang'. Eksploitasi hutan oleh perusahaan Kayu Kelapa Sawit, Karet dan sebagainya telah membuat lahan hutan habis. Kedekatan mereka dengan sawit semakin terlihat saat sebagian dari mereka bekerja sebagai buruh disana. Mereka dipekerjakan sebagai buruh untuk perawatan tanaman, pekerjaan kasar sawit yang tidak membutuhkan pengetahuan yang terlalu rumit. Selain karena tingkat kemampuan mereka yang terbatas mereka tidak punya pilihan lain untuk bekerja selain di perusahaan sawit. 
Gambar 5. Kebun Kemitraan Kelapa Sawit Longsep

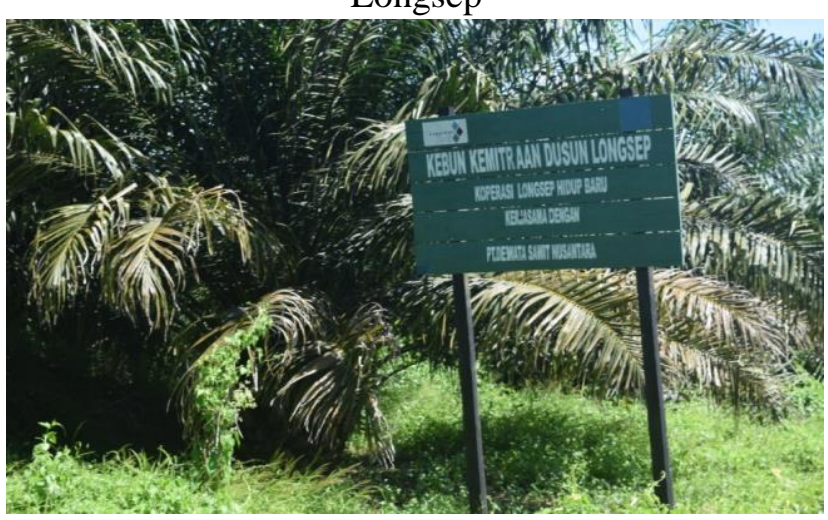

Sumber: Dokumentasi pribadi

Warga Longsep dibangunkan kebun kemitraan seperti pada gambar 5, lokasinya tepat di sekitaran pemukiman. Setiap lahan yang dimitrakan dengan perusahaan harus memiliki badan hukum. Begitu pula di Longsep, dibentuk sebuah koperasi untuk mendapatkan legalitas badan hukum. Koperasi Longsep Hidup Baru adalah pilihan nama untuk koperasi di Longsep.

Koperasi ini di ketuai oleh Awun yang diantara warga Longsep memiliki kelebihan pada kemampuan komunikasi dan berpikir lebih terbuka. Walaupun sempat mengalami pendidikan sekolah dasar, Awun tidak menyelesaikan sekolahnya. Mengetahui keterbatasan keahlian Orang Punan Longsep mengelola lembaga koperasi, perusahaan melalui departemen CSR nya memberikan pendampingan. Segala pengurusan legalitas yang diperlukan koperasi difasilitasi perusahaan. Kemudahan Orang Punan
Longsep untuk mendapatkan untung dari Kelapa Sawit semakin dirasakannya.

Kelapa Sawit menjadi bagian penting bagi Orang Longsep, selain bekerja sebagai buruh sawit mereka juga mendapatkan hasil dari kebun kemitraan mereka sendiri. Hal inilah yang menunjukkan bahwa Wacana Kelapa Sawit telah menjadi bagian dari hidup Orang Punan di Longsep. Ini yang mendasari anggapan bahwa mereka tak berdaya tanpa sawit. Kedekatan Orang Punan di Longsep dengan perusahaan semakin nyata tersiratkan dari pernyataan Awun membicarakan kebun kemitraan Koperasi Longsep Hidup Baru seperti berikut; "...hanya perusahaan yang cukup mengetahui tentang pengelolaan kebun. Karena perusahaan taat aturan.... Saya sudah sakit, nggak mungkin saya tambah disakiti perusahaan. "13

Pernyataan ini menegaskan bahwa perusahaan sebagai pihak yang dapat dipercaya/ diandalkan dan 'baik'. Terbentuknya citra perusahaan ini merupakan bagian dari strategi perusahaan melalui departemen CSR.

\section{Wacana Perusahaan}

Keberadaan Orang Punan di Longsep yang termasuk dalam areal HGU telah di enclave sejak status HGU masih izin lokasi. Sebagai pihak terdekat perusahaan bertanggung jawab untuk mendampingi Longsep. Salah 
satu bentuk tanggung jawab perusahaan dinyatakan dari pembangunan rumah layak huni untuk Orang Punan Longsep. Seperti yang dikatakan Nandar Manager CSR divisi Community Development; “...tahun 2010 kita (perusahaan) punya proyek rumah layak huni untuk Orang Longsep dan selesai tahun ini (2017), ... program itu untuk membuat mereka punya tempat, karena biasanya mereka tinggal di hutan, dipohon atau berladang berminggu-minggu..." ${ }^{14}$ Program pembangunan rumah layak huni merupakan dari inisiatif perusahaan. Pembangunan 17 rumah disesuaikan pada jumlah KK (Kepala Keluarga) yang ada pada tahun proyek itu dimulai.

Gambar 6. Beberapa rumah yang dibangunkan perusahaan

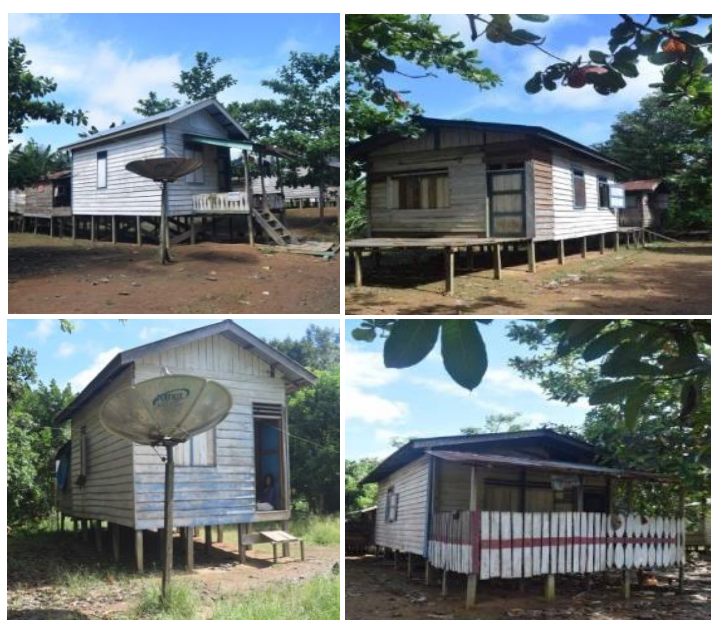

Sumber: Dokumentasi pribadi

Pembangunan rumah layak huni yang diharapkan perusahaan merupakan hal yang paling nampak ketika kita ke Longsep. Namun ada peran lain dari perusahaan seperti yang nampak pada Gambar.6, ada beberapa rumah yang telah memiliki parabola. Beberapa rumah telah mengakses televisi. Listrik tersedia atas bantuan perusahaan memberikan mesin generator pembangkit listrik dan bahan bakarnya. Selain itu pembangunan sanitasi jamban di sungai, juga pembangunan kebun buah merupakan beberapa program perusahaan.

\section{Simpulan}

Mendefinisikan Punan terlebih di Longsep tidak lagi sebagai kelompok yang asing, terbelakang terlebih liar. Namun menjadi lebih tepat bila mendefinisikan Orang Punan di Longsep adalah sebagai kelompok yang jarang berinteraksi dengan orang luar komunitasnya, (pemalu/segan dan kurang mendapat perhatian dari pihak-pihak yang berwajib) serta telah mengalami perubahan kearah modernitas/kemajuan dalam kehidupannya atas peran wacana-wacana yang beterbangan. Dari wacana-wacana beterbangan tersebut terdapat wacana dominan yang mempengaruhi wacana lain. Wacana yang nampak dominan adalah wacana perusahaan. Ini terlihat saat wacana perusahan masuk menyentuh aspek kebutuhan pendidikan dengan pengadaan program dan fasilitas pendidikan, kebutuhan ekonomi dengan pembangunan rumah beserta fasilitasnya dan kebun kemitraan terlebih Orang Longsep bekerja sebagai buruh tenaga lepasnya. Hal ini menguatkan 
pernyataan bahwa perusahaan telah sungguh membuat Orang Punan Longsep 'terkunci' tidak dapat berbuat sesuatu tanpa perusahaan..

Atas prakarsa perusahaan Kelapa Sawit hadir dekat dengan keseharian Orang Punan di Longsep. Sawit menjadi akrab dengan mata, telinga dan rasa Punan Longsep. Wacana-wacana perusahaan berperan besar pada perubahan hidup Punan Longsep. Hasil negosiasi terhadap wacana dominan ini memperlihatkan sekaligus memperkuat hipotesa bahwa 'perusahaan telah mendominasi hidup Orang Punan Longsep’

Berbagai pihak yang terkait (pemerintah, pihak perusahaan) perlu merumuskan kebijakan yang 'tepat' bagi Orang Punan di Longsep sebagai kelompok yang memiliki hak layaknya warga negara. Artikel ini adalah hasil observasi yang akan dilanjutkan dengan penelitian pada waktu berikutnya guna mendapatkan gambaran lebih mendalam tentang Punan Longsep.

\footnotetext{
${ }^{1}$ Soaduon Sitorus dkk, 2004. Potret Punan Kalimantan Timur: Sensus Punan 2002-2003, Indonesia, Center for International Forestry Research., hlm iv

2 Carl Bock, "I was now intending to penetrate into the forest.... and endevaour if possible to solve for myself the mystery of the Orang Poonan or Wild People of the Woods"... I believe these savages to be true aborigines of Borneo. They live in utter wildness in the central forest of Borneo, almost entirely isolated from all communicationwith the rest of the world"
}

Carl L. Hoffman, 1988, The "Wild Punan" of Borneo: A Matter of Economics, dalam Michael R. Dove (ed) The Real and Imagined Role of Culture in Development; Case Studies From Indonesia, USA, University of Hawai Press., hlm 90

${ }^{3}$ The Punan, grouped into small bands of hunters and gatherers of forest products..., they usually live upstream from Dayak..."

Nicolas Cesard, 2007, A Sociohistorical Transistion: Trade in Forest Products and Bride-Price among the Punan Tubu of Eastern Kalimantan, dalam jurnal Anthropos, Freiburg, Ricarz Publikation-service GMBH., hlm 455

${ }^{4}$ Wawancara dengan Awun pada 26 November 2017

${ }^{5}$ www.potensi-indonesia.com, diakses terakhir 25 Maret 2018

6 Wawancara dengan Awun pada 26 November 2017

${ }^{7}$ Wawancara dengan Awun pada 26 November 2017

${ }^{8}$ www.legalakses.com/hak-guna-usaha/ diakses terakhir pada tanggal 27 Maret 2018

${ }^{9}$ Sebelum observasi di Longsep dilakukan Orang Punan berada dalam administrasi Desa Miau Baru Kecamatan Kongbeng, pada percakapan dengan aparat desa Miau Baru dinyatakan bahwa letak administrasi Longsep menjadi tanggung jawab desa Muara Wahau, Kecamatan Muara Wahau.

${ }^{10}$ Informasi dari karyawan Perusahaan Kebun Kelapa Sawit Dewata Sawit Nusantara.

${ }^{11}$ Wawancara dengan Juman Ngau (gembala/pendeta gereja di Longsep) pada 20 November 2017

${ }^{12}$ Wawancara dengan Awun pada 29 November 2017

${ }^{13}$ Wawancara dengan Awun pada 29 November 2017

${ }^{14}$ Wawancara dengan Nandar pada 02 Desember 2017 


\section{Daftar Pustaka}

\section{Buku}

Schiffin, Deborah. 2007. Anjangan Kajian Wacana, terjemahan Approach To Discourse, ed Prof. Dr. Abd. Syukur Ibrahim, Pustaka Pelajar, Yogyakarta.

Mulyana. 2005. Kajian Wacana: Teori, Metode \& Aplikasi Prinsip-prinsip Analisis Wacana, Penerbit Tiara Wacana, Yogyakarta.

Sitorus, Soaduon dkk. 2004. Potret Punan Kalimantan Timur: Sensus Punan 20022003, Center for International Forestry Research, Indonesia.

\section{Artikel}

Cesard, Nicolas. 2007. A Sociohistorical Transistion: Trade in Forest Products and Bride-Price among the Punan Tubu of Eastern Kalimantan, dalam jurnal Anthropos, Ricarz Publikation-service GMBH, Freiburg.

Colfer, Carol J. P. 1983. Change and Indigenous Agroforestry in East Kalimantan, ResearchGate.

Hoffman, Carl. 1988. The "Wild Punan" of Borneo: A Matter of Economics, dalam Michael R. Dove (ed) The Real and Imagined Role of Culture in Development; Case Studies From Indonesia, University of Hawai Press, USA.

\section{Internet}

www.disbun.kaltim.go.id, diakses terakhir pada 25 Maret 2018

www. potensi-indonesia.com, diakses terakhir 25 Maret 2018

www.legalakses.com/hak-guna-usaha/

diakses terakhir pada tanggal 27 Maret 2018.

www.bpn.go.id, Peraturan Menteri Agraria dan Tata Ruang/ Kepala Badan
Pertanahan Nasional., diakses terkhir pada tanggal 27 Maret 2018.

\section{Wawancara}

Guk adalah tokoh masyarakat Longsep. Dia merupakan salah satu orang dari tujuh orang yang pertama kali tiba pada tahun 1979 di daerah sungai Wahau (Longsep).

Awun adalah Ketua Koperasi Longsep Hidup Baru dan tokoh masyarakat Longsep. Dia tinggal di Longsep sejak tahun 2008.

IG Sunandar adalah manager CSR (Corporate Social Responsibility) divisi Community Development yang salah satunya membawahi bidang pendidikan dalam operasional CSR PT DSN Group (PT Swakarsa Sinarsentosa, PT Dharma Intisawit Nugraha, PT Dewata Sawit Nusantara, PT Karya Prima Agro Sejahtera, P T Dharma Agro Nugraha). 